Article

\title{
Competition in the European Arena: How the Rules of the Game Help Nationalists Gain
}

\author{
Zoe Lefkofridi \\ Department of Political Science and Salzburg Center of European Studies, University of Salzburg, 5020, Salzburg, Austria; \\ E-Mail: zoe.lefkofridi@sbg.ac.at
}

Submitted: 30 September 2019 | Accepted: 20 January 2020 | Published: 13 February 2020

\begin{abstract}
Why does the European election fail to produce competition between European policy alternatives despite the increased politicization of European integration and efforts to connect election results to the Commission Presidency via the Spitzenkandidaten process? In this article I theorize the European arena's incentive structure for political competition by synthesizing Strøm's (1990) behavioral theory of competitive parties (votes, office, policy) and Bartolini's (1999, 2000) four dimensions of electoral competition (contestability, availability, decidability, and incumbent vulnerability). I model EU decidability (party differentials on EU policy) and formulate specific expectations about party differentiation by considering parties' vote-, office-, and policy-seeking motives under the European arena's specific conditions. How parties behave under the specific incentive structure of the European arena matters for the EU's development as a polity.
\end{abstract}

\section{Keywords}

dimensions of competition; European election; European Parliament; European Union; political parties; party goals

\section{Issue}

This article is part of the issue "Political Behavior in the EU Multi-Level System" edited by Daniela Braun (LMU Munich, Germany), Martin Gross (LMU Munich, Germany) and Berthold Rittberger (LMU Munich, Germany).

(C) 2020 by the author; licensee Cogitatio (Lisbon, Portugal). This article is licensed under a Creative Commons Attribution 4.0 International License (CC BY).

\section{Introduction}

Research on the European Parliament (EP) as a legislative arena shows that there is not only a high degree of policy coherence and cohesive voting behavior within European Political Groups (EPGs) but also clear differentiation and competition between EPGs on key policy issues (e.g., Hix, Kreppel, \& Noury, 2003; Lefkofridi \& Katsanidou, 2018; McElroy \& Benoit, 2010; but see also Cicchi, 2011). However, transnational policy differentiation between alliances in the European parliamentary arena has consistently failed so far to translate to 'translate' in the European electoral arena.

Contestation over transnational policies in the EP electoral arena would increase European Union (EU) policy responsiveness to the (changing) preferences of EU citizens, thus benefiting European democracy (Follesdal \& $\mathrm{Hix}, 2006)$. Although the EPG system has long since grown strong and "ready for power" (Hix et al., 2003), it has not transformed into a transnational party system that offers
EU voters alternative European policy options to choose from. Seeking to address this deficit, the EP made use of a new Treaty article (EU, 2007, Article 17[7]) that links the Head of the Commission to the results of European elections and came up with the Spitzenkandidaten experiment in 2014 (see Hobolt, 2014), a system which it preserved up until the 2019 election. Note that this occurred after significant EP empowerment (e.g., the expansion of policy areas subject to co-decision; EU, 2007) and at a time of high levels of politicization of European integration. As recent empirical research has convincingly shown, however, the experiment had limited success (Braun \& Popa, 2018; Braun \& Schwarzbözl, 2019). A persistent deficit of EP elections continues to be the absence of competition among alternative transnational policies. While EU issues play an increasing role in the European electoral arena, this arena remains dominated by national issues or EU polity issues that are not subject to the EP's jurisdiction (Braun, Hutter, \& Kerscher, 2016; Lefkofridi \& Kritzinger, 2008; Novelli \& Johansson, 2019). 
Why does the European election fail to produce competition between European policy alternatives even in spite of the increased politicization of European integration and efforts to connect its results to the Commission Presidency via the Spitzenkandidaten? In this article I present a model of the actual choice likely to be offered by vote-, office-, and policy-seeking parties under the specific conditions of competition in the European arena. This model synthesizes insights from Strøm's (1990) behavioral theory of competitive parties (votes, office, policy) and Bartolini's $(1999,2000)$ four dimensions of electoral competition (contestability, availability, decidability, and incumbent vulnerability). Using this model of the European arena as a political-electoral 'market,' I highlight major obstacles to EU policy responsiveness that relate to the supply and demand of transnational policy competition.

Debates about the EP election's connection to EUlevel executive office through Spitzenkandidaten often overlook the barriers to enter this competition in the first place. Although such barriers to entry may be variably low for national-level newcomers and outsiders, they are universally high for transnational ones (low EU-level contestability). As such, these barriers encourage nationalist vote- and policy-seeking strategies as opposed to transnationalist strategies. In spite of a growing transnational cleavage (Hooghe \& Marks, 2018) and large numbers of potentially 'available' voters (who might be willing to switch from national to supranational policy suppliers), these voters remain trapped in segmented electoral markets (low EU-level availability). As it stands, therefore, the European arena discourages the transnational expression of support for or opposition to EU policies on both the supply and demand sides of competition. By inhibiting competition over transnational (as opposed to national) policy alternatives (EU-level decidability), this arena traps European citizens and elites in a futile debate in favor of or against the EU as a whole. Crucially, as long as the debate is structured not in EU policy but in EU polity terms (pro/anti-EU), nationalists have an advantage because their basic ideology (nationalism versus Europeanism) structures the competition. This means that where there is a growing transnational cleavage (Hooghe \& Marks, 2018), then the transnational part of that cleavage is disenfranchised by the way in which EP elections are conducted. Under current conditions, the connection of the EP results to the Commission Presidency is unlikely to produce the desired results in terms of transnational expression of support for or opposition to EU policies (EU policy differentiation). Unless structural change is pursued, therefore, the very rules of the EP game will continue to help nationalists gain.

\section{Party Goals and Conditions of Competition}

I assume that parties are purposeful actors pursuing votes, policy, and office (Strøm, 1990). Parties aim at increased electoral shares, enhanced advocacy of their ideologies, and the attainment of executive power in the form of politically discretionary governmental and sub-governmental appointments (Bartolini, 1999, 2000; Pedersen, 2012; Strøm, 1990). While vote-seeking addresses the electorate at large (public opinion), policyseeking is a goal closely linked to parties' ideologies and their partisans (de Sio \& Weber, 2014; Lefkofridi \& Nezi, 2019) aimed at strengthening advocacy for ideologies supported by core segments of the electorate who identify with a specific party instead of others.

The feasibility of each goal is conditioned by institutional opportunities and constraints, which further shape the trade-offs that parties face between these goals (Müller \& Strøm, 1999, pp. 5-13). A strategy of optimizing votes, for example, may render a party unacceptable as a cabinet coalition partner by other parties on policy grounds, while to achieve office a party may sacrifice policy or "soft-pedal" issues and policy promises that could maximize its votes (Bartolini, 2000, p. 44).

\subsection{EP Empowerment, Politicization, and Contestation over EU Policies}

Party contestation over EU policies in the EP arena was expected to benefit from the politicization of European integration, the EP's empowerment, and the connection of the European election's outcome with the Commission Presidency (Bardi et al., 2010; Follesdal \& Hix, 2006; Hix, 2002, 2013). The Lisbon Treaty (EU, 2007) established the EP as a co-legislator on an equal footing with the Council and linked EP election results to the Commission Presidency. As a result, in 2014 and 2019 some EU-level parties appointed lead candidates for the post of Commission President. The Spitzenkandidaten system operated during a decade of unprecedented levels of politicization of the EU and its policies, generated by multiple crises (the economic and financial crisis, the migration crisis, and Brexit). Taken together, these developments should have generated "greater incentives for stronger party organizations and greater possibilities for parties to shape EU policy outcomes in a particular ideological direction" (Hix, Noury, \& Roland, 2005, p. 211). Politicization should have strengthened vote-seekers' incentives to invest in EU issues for electoral gains; the strengthening of the EP should have enhanced policyseekers' interest in EU-level advocacy of their ideology; and the Spitzenkandidaten experiment should have motivated office-seekers to engage in a transnational contest over the Presidency.

In the most recent (2019) election, the key dividing line was (still) less about different visions of the Union and accompanying policy proposals to implement these visions than about whether we want the Union or not. Turnout increased for the first time, however, and EU voters broke the historical pattern of electing a combined majority held by two major mainstream pro-EU party families (i.e., Christian and Social Democrats). The winners of this election were either clearly pro-integration 
parties, such as the Greens and the Liberals, or the most obviously anti-integration forces, such as the far-right Identity and Democracy group. One winning group sees the EU as an opportunity for their prime policy goals (environmentalism, liberalism), while the other sees it as a major obstacle to their goals (nationalism). While this result constitutes evidence of a rising transnational cleavage (Hooghe \& Marks, 2018), as long as the debate is structured not in policy but in polity terms (pro/antiEU dimension), nationalists will continue to have an advantage because their basic ideology (nationalism versus Europeanism) structures the competition. Below I will argue that the specific conditions of competition in the EU arena encourage nationalist vote-and policy-seeking strategies while hampering transnationalist vote- and policy-seeking strategies.

Competition is understood here as the process through which parties try to shape (to their advantage) the structure of electoral preferences (Bartolini, 1999, 2000). To understand how and which types of goaloriented behavior would result in more or less EU policy differentiation, we first need to specify how different conditions of competition incentivize vote-, policy- and office-seeking parties to differentiate (or obfuscate) the EU policy offer. For this purpose, I review the general conditions under which parties compete and present a model of decidability (policy differentiation).

\subsection{Conditions of Competition}

Bartolini's (1999, 2000) framework identifies four empirical dimensions of politico-electoral competition:

- Contestability: The rules of the game that structure political opportunities for old and new contestants (Bartolini, 1999, p. 460), including legal eligibility requirements to stand for and vote in an election and thresholds for seat distribution;

- Availability: The quota of available voters who are "willing to consider changing their party choice," or the potential for electoral volatility (Bartolini, 1999, p. 465);

- Decidability: The level of actual choice available to voters (Bartolini, 2000, pp. 34-51);

- Incumbent vulnerability: The likelihood of incumbents being replaced as a result of changes in voters' choices (Bartolini, 2000, pp. 52-55).
Given the interconnectedness of these four dimensions, any empirical theory of competition must link one dimension with another by highlighting what "consequences each entails for the other" (Bartolini, 2000, p. 61). Since responsiveness is a key concern in the debate about EU-level contestation, here I will focus on decidability, which, along with incumbent vulnerability, constitutes a necessary condition for responsiveness. While the vulnerability of incumbents is a necessary condition for decidability, however, it is not sufficient of itself (Bartolini, 2000).

In Bartolini's (2000) model, decidability is assumed to be dependent not only upon incumbent vulnerability but also upon contestability and availability (Table 1). Differentiation in the policy offer between parties is expected under the following conditions: First, when barriers to newcomers in the political market are low (high contestability $\uparrow$ ); second, when a considerable part of the electorate is willing to switch along the key dividing lines (high availability $\uparrow$ ); third, when voters are able to reward or sanction incumbents (high vulnerability $\uparrow$ ). Table 1 summarizes this proposition and visualizes the relationships involved.

\section{Contestability, Availability, and Incumbent Vulnerability in the European Arena}

Applying this model we would expect EU decidability (which concerns levels of differentiation and clarity in the EU positions offered by parties) to be generated by low barriers to transnational policy supply and demand, tougher with high EU-wide availability of voters willing to switch between EU-level parties, and high capacity of the EU-wide electorate to sanction EU-level incumbents. Given that such conditions would serve to incentivize transnationalist vote-, policy- and office-seeking, the first question that must be addressed is whether such conditions exist.

Until now, the political and scholarly debates have concentrated on strengthening the electoral connection to an EU-level office (incumbent vulnerability) as a means of incentivizing office-seeking parties to engage in an arena which (for them) is regarded as a "beauty contest" (van der Brug, van der Eijk, \& Franklin, 2007). However, the strong focus of this debate on officeseeking parties and their lack of engagement overlooks the fact that incumbent vulnerability alone is not a sufficient condition for decidability. In the following, I place

Table 1. Supply and demand conditions of political competition (Bartolini, 1999, 2000).

\begin{tabular}{lccc}
\hline SUPPLY & DEMAND & $\begin{array}{c}\text { Availability } \\
\text { (voters willing to switch) }\end{array}$ & $\begin{array}{c}\text { Decidability } \\
\text { (party differences) }\end{array}$ \\
\hline $\begin{array}{l}\text { Contestability } \\
\text { (high when barriers to enter are low) }\end{array}$ & $-\uparrow$ & $\uparrow$ & $\uparrow$ \\
$\begin{array}{l}\text { Incumbent Vulnerability } \\
\text { (high when executive tenure is not safe) }\end{array}$ & $\uparrow$ & $\uparrow$
\end{tabular}


a strong focus on the barriers to entry, which helps in assessing the degree to which transnationalist/nationalist vote- and policy-seeking strategies are encouraged or discouraged. By combining this dimension with the vulnerability and availability dimensions we can assess the consequences for EU-level policy differentiation in a more comprehensive manner.

\subsection{Contestability}

The 1976 Direct Election Act establishes some common basic principles, but national laws regulating contestability in the EP arena differ. Since 2002, all members use some form of proportional representation with varied list systems that provide different incentives to create a strong connection between deputies and electorates (Hix \& Hagemann, 2009). For countries using disproportional rules in domestic elections (e.g., France, Greece, and the UK), the European election grants easier access to willing competitors. Precisely because the EP election does not lead to government formation and is conducted using proportional electoral rules, (small) parties lacking "governing potential" (Sartori, 1976) at national level are likely to seek those votes that they would not receive in national elections, especially in systems where ballots cast for third-parties are "wasted" (Mueller, 2003).

That being said, the threshold for seat allocation used across the EU varies, ranging from $0 \%$ to $5 \%$. Many EU member states (Belgium, Bulgaria, Denmark, Finland, Germany, Estonia, Ireland, Luxembourg, Malta, Portugal, Slovenia, Spain, and the UK) employ no threshold at all. Cyprus and Greece set the threshold at $1.8 \%$ and $3 \%$ respectively, while Austria, Italy and Sweden employ a $4 \%$ threshold. In nine EU member states (Croatia, the Czech Republic, France, Hungary, Latvia, Lithuania, Poland, Romania, and Slovakia), competitors face the highest threshold of $5 \%$ (EP, 2019). Where thresholds are low, vote- and policy-seeking incentives are stronger for small existing parties, as well as for new competitors for whom the EP arena may serve as a 'back door' for entering their national electoral arenas (e.g., Alternative für Deutschland). Even stronger incentives to seek votes in the EP arena are provided in countries where parties become eligible for public funding once they have received a specific number of votes in the EP election, including Greece, Germany, and Portugal (see van Klingeren, Orozco, van Spanje, \& de Vreese, 2015).

There is also variation in the right to stand for election in the European arena. Besides national differences in the minimum age required for candidacy, candidacies are restricted to $\mathrm{EU}$ citizens who are nationals of $\mathrm{x}$ member state or residents of $x$ member state that satisfy the same requirements that each member sets for its own nationals (EP, 2019, Article 10, Council Directive 93/109/EC). To stand as a candidate in Luxembourg, for instance, where the foreign population exceeds $20 \%$ of the electorate, a residence period of five years is required. Such residence requirements disadvantage mo- bile EU citizens who move frequently between member states for work purposes. While nominations may only be submitted by political parties and political organizations in some EU member states, in other states nominations may be endorsed by a required number of signatures, ranging from 5,000 in Belgium to 150,000 in Italy (Alemanno, 2018; EP, 2019). Candidate nomination and selection procedures, in turn, impact the kind of activities in which deputies engage once elected (Euchner \& Frech, 2020).

Last but not least, no person may stand as a candidate in more than one EU country in the same election (Article 4, Council of the EU, 1993). This last provision closes the market to candidates with an ambition to mobilize voters in more than one member state, which would necessitate a transnational policy platform. To address this deficit, Andrew Duff, a Member of the EP (MEP), developed a proposal for transnationalizing electoral lists-an idea that was discussed in light of Brexit (see Verger, 2018). This proposal for the first "really panEuropean" constituency was rejected in the EP's final plenary vote in February 2018 (VoteWatch EU, 2018). The failure of the proposal was due not only to Eurosceptics but also to the members of the European People's Party (EPP) that currently dominates EU institutions.

The rules of the EP game as they currently stand provide a relatively open politico-electoral market to national-level competitors in most (but not all) member states. Wherever and insofar as the EP lowers the barriers to enter the competition, the EP arena is likely to be highly valued and utilized by outsiders/newcomers and small existing competitors to increase their electoral strength and/or reinforce their policy influence in the EP. Provided that national parties can find congruent counterparts and form EPGs, they can use the European arena for forming common policy fronts against their competitors. Green parties did exactly this and managed to bring about policy changes to their national systems via successful coordination at EU level (Bomberg, 2002).

That said, the EP arena sets high barriers to the entry of new transnational competitors such as, for example, the pan-European movements Diem 25 and Volt. Fielding candidates in 28 different member states with different national provisions complicates the strategies of transnational movements willing to engage in the arena. In some member states the $5 \%$ threshold may be too high to overcome for new transnational organizations competing against national parties that are organizationally entrenched in domestic systems. Volt ran candidates in eight different countries and won only one seat, for example, while Diem 25 fielded candidates in eleven countries but failed to gain any seats at all, even in Greece where one of its (famous) founders, Yanis Varoufakis, won $2.99 \%$ of the vote. This is because EU-level contestability of the EP arena is very low (high barriers), which undermines the vote- and policy-seeking efforts of transnational political entrepreneurs seeking to diversify the EU policy offer. 
Barriers to entry also concern the right to vote, hence it is worth highlighting that voting methods vary for EU citizens resident abroad (Sabbati, Sgueo, \& Dobreva, 2019; see also SpaceEU, 2019). On the basis of the free movement of labor, EU citizens can seek jobs in different member states, which results in increasing mobility within the EU territory. In 2017, about 17 million (4\% of the EU's working population) were living in a country other than their member state of origin, while an additional 1.4 million constituted cross-border workers (European Commission, 2018). Mobile EU citizens are confronted with complex procedures and varied deadlines for electoral registration in their countries of residence or of origin, often needing to travel to distant cities if no voting booth is provided where they live. These EU citizens are the most likely to have preferences for or against specific transnational policies, but the European arena makes exercising their democratic right particularly cumbersome. This implies that those "who are in effect building Europe from the bottom up, along with their lives and families" face more difficulties in steering its political future (Alemanno, 2019). Setting high barriers to voters who are likely to have preferences for specific EU policies thus weakens the incentives for vote-seeking parties to address these preferences.

\subsection{Availability}

The organizational encapsulation of voters has been in decline in Western Europe, while it has never been very strong in Central-Eastern Europe (Rohrschneider \& Whitefield, 2012; van Biezen, Mair, \& Poguntke, 2012). In the EU as a whole there is a high availability of voters, which is manifested through low voters' scores of various indicators such as party identification and party membership, and higher electoral volatility (e.g., Kriesi \& Pappas, 2015 , p. 2). To date, these large amounts of available voters across the Union remain "encapsulated territorially." The fact that voters can only choose between those parties operating within the borders of a single member state (either the EU member state of their origin or of their residence) does not encourage the articulation of transnational policy alternatives by vote-seeking parties.
On the demand side the market is segmented, while the partisan connection between citizens and EU-level parties remains weak. This is due, amongst other factors, to the attitudes of Europarties' own national member parties towards individual membership, since strengthening European citizens' individual membership of Europarties would compete directly with national parties over their own (existing or potential) party members (Hertner, 2019). This holds true also for the Greens, despite being the most Europeanized party family (Bomberg, 2002). This effort by policy-seeking organizations to retain control over their partisans also impedes the transnational expression of preferences for/against EU policies.

\subsection{Incumbent Vulnerability}

The European arena is not bound to the alternation of executive power at EU level, which means safety of tenure. EU-level institutions cannot be (collectively) sanctioned for the policies they pursue, which disincentivizes officeseeking parties from EU-level differentiation. The missing connection between the EP arena and some kind of 'EU-level government' implies weak incentives for officeseeking parties to engage in this arena, and this has been regarded as the key obstacle towards the development of a transnational party system, the strengthening of transnational parties and, ultimately, contestation over EU policies in European elections (Bardi et al., 2010, p. 7; Follesdal \& Hix, 2006; Hix, 2002).

The specific conditions of competition in the EP arena are summarized in Table 2.

\section{Parties' Goals and the Consequences for Decidability in the European Area}

Approaching the European arena from the perspective of party goals under these specific conditions (as summarized in Table 2) generates three key insights. First, the multilevel structure separates party goals from one another, since the successful pursuit of each goal concerns different levels of aggregation in the same channel (national vs. EU-levels of EP representation) or even

Table 2. Conditions of competition in the EP arena.

\begin{tabular}{|c|c|c|c|}
\hline SUPPLY 'Protected' DEMAND 'Segmented' & $\begin{array}{l}\text { Availability } \\
\text { Territorially encapsulated; high } \\
\text { barriers to transnational citizens }\end{array}$ & & $\begin{array}{l}\text { Decidability } \\
\text { National-level and EU-level } \\
\text { differentiation }\end{array}$ \\
\hline $\begin{array}{l}\text { Contestability } \\
\text { Open to national competitors } \\
\text { Closed to transnational competitors }\end{array}$ & $\begin{array}{r}\text { NAT } \uparrow \\
\text { EU } \downarrow\end{array}$ & $\rightarrow$ & $\begin{array}{l}\text { NAT } \uparrow \\
\text { EU } \downarrow\end{array}$ \\
\hline $\begin{array}{l}\text { Incumbent vulnerability } \\
\text { 'Safety of Tenure-Inability to Sanction' } \\
\text { Arena very weakly connected to EU institutions' } \\
\text { executive power. }\end{array}$ & $\begin{array}{r}\text { NAT } \uparrow \\
\text { EU } \downarrow\end{array}$ & $\rightarrow$ & $\begin{array}{c}\text { NAT } \downarrow \\
\text { EU } \downarrow\end{array}$ \\
\hline
\end{tabular}


different institutions (national government, EU Council, Commission); hence strategies to optimize votes or policy have no direct repercussions for office-seeking, which is served by another arena. Moreover, although a conflict between vote- and policy-optimization is possible (a strategy optimizing votes may alienate EPG partners), EPGs' strength in the assembly (seats), and consequently their potential for policy influence, strongly depends upon the success of EPG members' national level voteseeking strategies.

Second, the European arena serves some party goals (votes, policy) but not all (office). Among those party goals that are feasible in the EP arena, vote-seeking appears easier than policy-seeking. Successful policyseeking requires both mobilizing partisans and joining a congruent EPG after the election. Hence, although the European arena provides an important opportunity for policy-seeking, it requires some effort (see also Pittoors, 2020). At the same time, transnationalist vote-seeking is discouraged through barriers to entry and the territorial encapsulation of (potentially available) voters.

Third, under the current conditions of competition in the EP arena (closure of the supply market to transnational supplies, territorial encapsulation of demand, and safety of EU-level executive tenure), party goals incentivize parties to structure competition in different ways, with consequences for EU-level policy differentiation (summarized in Table 3).
Since ideology matters for party positions on specific EU policies (Hooghe, Marks, \& Wilson, 2002), policyseekers should by definition be more likely to structure contestation on EU policy issues and thus enhance EU-level policy differentiation. And while parties, once elected, make policy for all Europeans (not just their domestic voters), they compete for the electoral support of domestic voters only. In this competition, policyseekers must compete successfully against vote- and office-seeking parties (who employ different strategies, see below) in an arena with low levels of EU-level contestability. Even the most fervent transnational policyseekers must first win the support of enough domestic voters to pass the threshold if they want to succeed in their EU level policy pursuit. In a market of territorially segmented voters, policy-seeking parties have little to gain electorally by structuring competition along the national versus transnational dividing line (Table 3).

Under the same conditions, office-seeking considerations motivate parties to structure competition along the government/opposition dimension (government disapproval) and to utilize the European election as a popularity test of the domestic government's performance (Table 3). By structuring competition along the incumbent-opposition dimension, the EP "beauty contest" (van der Brug et al., 2007) provides office-seekers with valuable information about 'available' voters' preferences and behavior that they can use as a basis for de-

Table 3. Dimensions of competition and party goals.

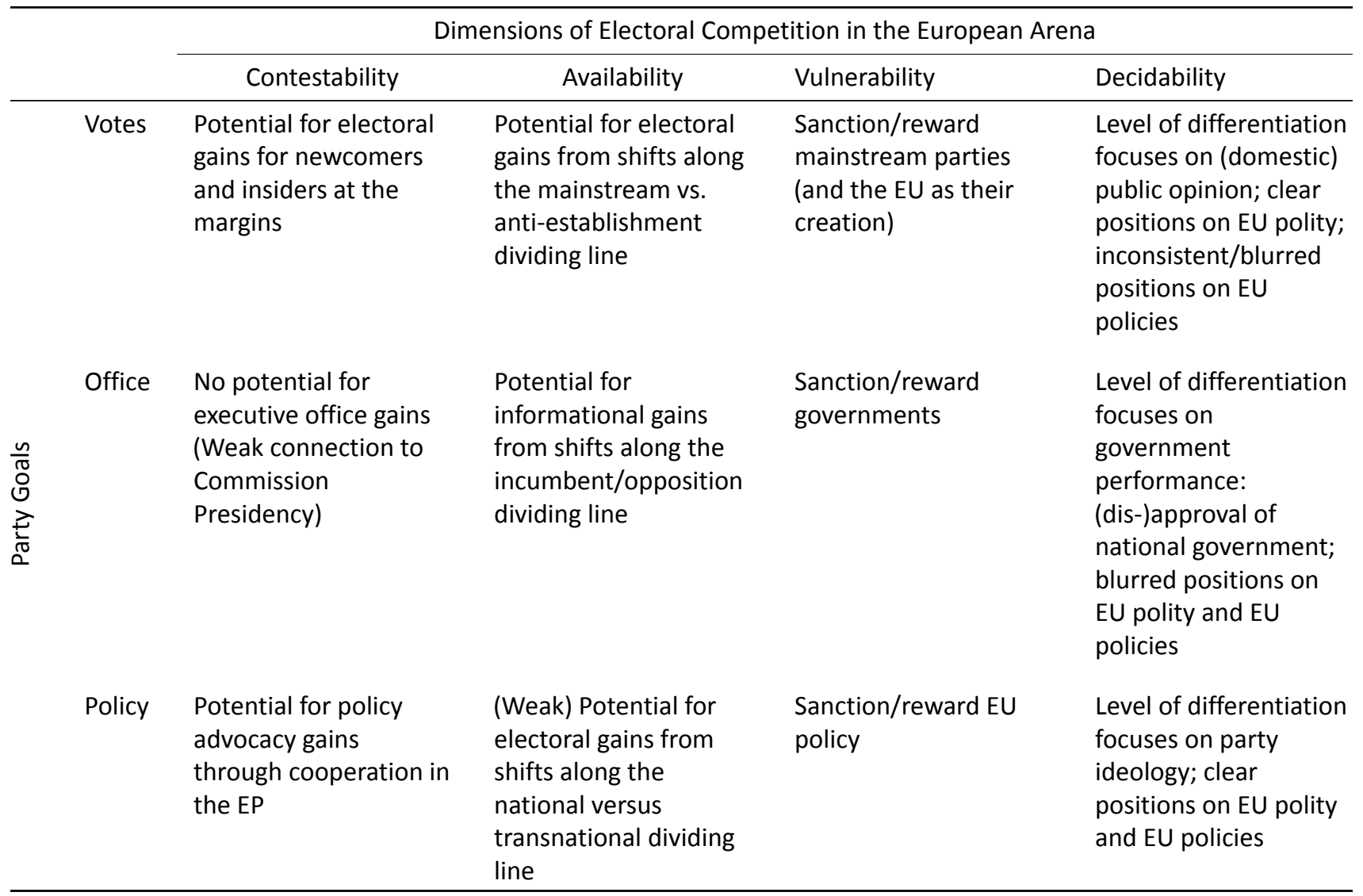


vising strategies to gain office at the next national election. At the same time, vote-seekers are motivated to structure competition along the insiders vs. outsiders (mainstream vs. anti-establishment) conflict line and benefit from the high availability of voters (Table 3 ). Note that vote-seeking considerations imply the instrumental use of both national and EU (polity and policy) issues, depending on what 'sells' best within the respective electorate at a given point in time (see also HeinkelmannWild, Kriegmair, \& Rittberger, 2020). Greater clarity of positions among vote-seekers is expected on the polity dimension (pro-/anti-EU) and on those specific EU policy issues from which parties can gain electorally in the given (domestic) context. To incentivize parties to campaign on transnational rather than national issues, Europe's voting space should be (even if only partially) transnationalized (Bright, Garzia, Lacey, \& Trechsel, 2016).

\section{Conclusion: How the Rules of the Game Help Nationalists Gain}

The 'second-order national election theory' of EP elections centers on turnout and government party losses (Reif \& Schmitt, 1980; Schmitt, Sanz, Braun, \& Teperoglou, 2020). The focus of this and related theorizing (for a discussion, see Marsh, 2009) is on voting behavior, while the locus of explanation for EP election results lies in the national arena (electoral cycle/rules, etc.). In this narrative, European elections are likely to cease being dominated by national issues once European issues penetrate the national arena, which is what has happened during multiple crises. Here I focus on party behavior and locate the explanation in the European arena itself. Since parties embody the link between the citizenry and EU institutions, party behavior is particularly important for understanding the relationship of European citizens and the EU polity, as well as the rise of Euroscepticism across Europe.

The argument I develop concerns barriers to the supply and demand of political competition and the ways in which the institutional setup of the European election undermines 'transnational policy' competition. Conceptualizing the EP arena as a political-electoral market (Bartolini, 1999, 2000) and examining the dimensions of competition in the EP arena in relation to one another sheds light on structural obstacles to political integration. Specifying the empirical conditions under which parties compete in this arena, using Bartolini's (1999, 2000) framework, reveals the consequences of vote-, policy-, and office-seeking behavior under the particular conditions of this arena.

How vote-, policy-, and office-seeking parties engage with the EP electoral arena has implications for decidability, understood here as the 'levels of actual choice' offered to European voters. Although the European arena is not appealing to office-seekers, it enables easier entry for willing vote- and policy-seeking outsiders, as long as these are national (as opposed to transnational) organi- zations. When political opposition cannot be expressed in transnational policy terms within the system, however, then it inevitably directs itself at the polity and the political personnel, which is exactly what nationalist and populist parties seeking votes have been doing, and which, in the absence of structural reform, they will keep on doing with success (Mair, 2007). If Europeans' opposition to EU policies cannot be of a transnationalist nature under the current structure, then such opposition is likely to be nationalist. In other words, the system inhibits the transnational expression of opposition to EU policies (which, however, is key for Europeans' capacity to influence supranational policy direction and for Europe's political integration). Since the rise of nationalist populist Euroscepticism is evidently detrimental to the European project, convinced Europeanists might want to consider changing the current incentive structures. Any future reform, however, needs to take into account not just one but all dimensions of electoral competition and the consequences each dimension entails for the others.

\section{Acknowledgments}

The author is grateful to three anonymous reviewers for their valuable critique and constructive suggestions. Earlier versions of this piece were presented at a workshop on 'Bringing Politics into the Study of the European Union' organized by Daniela Braun and Martin Gross at the Geschwister Scholl Institute of Political ScienceLMU Munich, Munich, on 15-16 November 2018, and at the workshop on 'Electoral Democracy and European Integration: How the Current EU Crisis Affects Voters and Elections in the European Multilevel Electoral System' organized by Hermann Schmitt and Eftichia Teperoglou at the ECPR Joint Sessions of Workshops, Mons, Belgium, on 8-12 April 2019. The author is grateful to the organizers and participants for their useful comments and suggestions.

\section{Conflict of Interests}

The author declares no conflict of interests.

\section{References}

Alemanno, A. (2018). Towards transnational European democracy? The new battle lines of the 2019 European Parliament election (HEC Paris Research Paper No. LAW-2018-1287). Jouy-en-Josas: HEC Paris.

Alemanno, A. (2019, May 1). There are 17 million mobile EU citizens: We deserve a political voice. The Guardian. Retrieved from https://www.theguardian. com/commentisfree/2019/may/01/17-millionmobile-eu-citizens-european-elections

Bardi, L., Bressanelli, E., Calossi, E., Gagatek, W., Mair, P., \& Pizzimenti, E. (2010). How to create a transnational party system. Brussels: European Parliament. Retrieved from https://cadmus.eui.eu/bitstream/ 
handle/1814/14744/StudyTransnational PartySystem.pdf?sequence $=1$ \&isAllowed $=y$

Bartolini, S. (1999). Collusion, competition and democracy: Part I. Journal of Theoretical Politics, 11(4), 435-470.

Bartolini, S. (2000). Collusion, competition and democracy: Part II. Journal of Theoretical Politics, 12(1), 33-65.

Bomberg, E. (2002). The Europeanisation of green parties: Exploring the EU's impact. West European Politics, 25(3), 29-50.

Braun, D., Hutter, S., \& Kerscher, A. (2016). What type of Europe? The salience of polity and policy issues in European Parliament elections. European Union Politics, 17(4), 570-592.

Braun, D., \& Popa, S. A. (2018). This time it was different? The salience of the Spitzenkandidaten system among European parties. West European Politics, 41(5), 1125-1145.

Braun, D., \& Schwarzbözl, T. (2019). Put in the spotlight or largely ignored? Emphasis on the Spitzenkandidaten by political parties in their online campaigns for European elections. Journal of European Public Policy, 26(3), 428-445.

Bright, J., Garzia, D., Lacey, J., \& Trechsel, A. (2016). Europe's voting space and the problem of second-order elections: A transnational proposal. European Union Politics, 17(1), 184-198.

Cicchi, L. (2011). Party groups in the European Parliament, cohesiveness and MEPs' survey data: New evidence on voting behaviour from a new (simple) methodology? Interdisciplinary Political Studies, 1(2), 137-147.

Council of the EU. (1993). Directive 93/109/EC. Brussels: European Union. Retrieved from https:// eur-lex.europa.eu/legal-content/EN/TXT/PDF/?uri= CELEX:31993L0109\&from=EN

de Sio, L., \& Weber, T. (2014). Issue yield: A model of party strategy in multidimensional space. American Political Science Review, 108(4), 870-885.

Euchner, E.-M., \& Frech, E. (2020). Candidate selection and parliamentary activity in the EU's multi-level system: Opening a black-box. Politics and Governance, 8(1), 72-84.

European Commission. (2018). 2018 annual report on intra-EU labour mobility. Brussels: European Commission. Retrieved from https://ec.europa.eu/ social/main.jsp?catld=738\&langld=en \&publd=8174 \&furtherPubs=yes

European Parliament. (2019). The European Parliament: Electoral procedures. European Parliament. Retrieved from https://www.europarl.europa.eu/ factsheets/en/sheet/21/the-european-parliamentelectoral-procedures

European Union. (2007). Treaty of Lisbon. Brussels: European Union. Retrieved from http:// publications.europa.eu/resource/cellar/688a7a983110-4ffe-a6b3-8972d8445325.0007.01/DOC_19
Follesdal, A., \& Hix, S. (2006). Why there is a democratic deficit in the EU: A response to Majone and Moravcsik. JCMS: Journal of Common Market Studies, 44(3), 533-562.

Heinkelmann-Wild, T., Kriegmair, L., \& Rittberger, B. (2020). The EU multi-level system and the Europeanization of domestic blame-games. Politics and Governance, 8(1), 85-94.

Hertner, I. (2019). United in diversity? Europarties and their individual members' rights. Journal of European Integration, 41(4), 487-505.

Hix, S. (2002). Linking national politics to Europe. London: Foreign Policy Centre.

Hix, S. (2013). What's wrong with the Europe Union and how to fix it. Hoboken, NJ: John Wiley \& Sons.

Hix, S., \& Hagemann, S. (2009). Could changing the electoral rules fix European Parliament elections? Politique Européenne, 28(2), 37-52.

Hix, S., Kreppel, A., \& Noury, A. (2003). The party system in the European Parliament: Collusive or competitive? JCMS: Journal of Common Market Studies, 41(2), 309-331.

Hix, S., Noury, A., \& Roland, G. (2005). Power to the parties: Cohesion and competition in the European Parliament, 1979-2001. British Journal of Political Science, 35(2), 209-234.

Hobolt, S. B. (2014). A vote for the President? The role of Spitzenkandidaten in the 2014 European Parliament elections. Journal of European Public Policy, 21(10), 1528-1540.

Hooghe, L., \& Marks, G. (2018). Cleavage theory meets Europe's crises: Lipset, Rokkan, and the transnational cleavage. Journal of European Public Policy, 25(1), 109-135.

Hooghe, L., Marks, G., \& Wilson, C. J. (2002). Does left/right structure party positions on European integration? Comparative Political Studies, 35(8), 965-989.

Kriesi, H., \& Pappas, T. S. (Eds.). (2015). European populism in the shadow of the great recession. Colchester: ECPR Press.

Lefkofridi, Z., \& Katsanidou, A. (2018). A step closer to a transnational party system? Competition and coherence in the 2009 and 2014 European Parliament. JCMS: Journal of Common Market Studies, 56(6), 1462-1482.

Lefkofridi, Z., \& Kritzinger, S. (2008). Battles fought in the EP arena: Developments in national parties' Euromanifestos. Österreichische Zeitschrift für Politikwissenschaft, 37(3), 273-296.

Lefkofridi, Z., \& Nezi, R. (2019). Responsibility versus responsiveness...to whom? A theory of party behavior. Party Politics. Advance online publication. https:// doi.org/10.1177\%2F1354068819866076

Mair, P. (2007). Political opposition and the European Union. Government and Opposition, 42(1), 1-17.

Marsh, M. (2009). Vote switching in European Parliament elections: Evidence from June 2004. European Inte- 
gration, 31(5), 627-644.

McElroy, G., \& Benoit, K. (2010). Party policy and group affiliation in the European Parliament. British Journal of Political Science, 40(2), 377-398.

Mueller, D. (2003). Public choice III. Cambridge: Cambridge University Press.

Müller, W. C., \& Strøm, K. (Eds.). (1999). Policy, office, or votes? How political parties in Western Europe make hard decisions. Cambridge: Cambridge University Press.

Novelli, E., \& Johansson, B. (Eds.). (2019). 2019 European elections campaign: Images, topics, media in the 28 member states. Brussels: European Parliament.

Pedersen, H. H. (2012). What do parties want? Policy versus office. West European Politics, 35(4), 896-910.

Pittoors, G. (2020). Living apart together? The organization of political parties beyond the nation-state: The Flemish case. Politics and Governance, 8(1), 50-60.

Reif, K., \& Schmitt, H. (1980). Nine second-order national elections: A conceptual framework for the analysis of European election results. European Journal of Political Research, 8(1), 3-44.

Rohrschneider, R., \& Whitefield, S. (2012). The strain of representation: How parties represent diverse voters in Western and Eastern Europe. Oxford: Oxford University Press.

Sabbati, G., Sgueo, G., \& Dobreva, A. (2019). 2019 European elections: National rules. Brussels: European Parliamentary Research Service. Retrieved from https://www.europarl.europa.eu/RegData/etudes/ ATAG/2018/623556/EPRS_ATA(2018)623556_EN.pdf Sartori, G. (1976). Party and party systems: A framework for analysis. Cambridge: Cambridge University Press. Schmitt, H., Sanz, A., Braun, D., \& Teperoglou, E. (2020). It all happens at once: Understanding electoral behavior in second-order elections. Politics and Governance, 8(1), 6-18.

SpaceEU. (2019). Homepage. SpaceEU2019. Retrieved from http://spaceu2019.eu

Strøm, K. (1990). A behavioral theory of competitive political parties. American Journal of Political Science, 34(2), 565-598.

van Biezen, I., Mair, P., \& Poguntke, T. (2012). Going, going,...gone? The decline of party membership in contemporary Europe. European Journal of Political Research, 51(1), 24-56.

van der Brug, W., van der Eijk, C., \& Franklin, M. (2007). The economy and the vote: Economic conditions and elections in fifteen countries. Cambridge: Cambridge University Press.

van Klingeren, M., Orozco, M., van Spanje, J., \& de Vreese, C. (2015). Party financing and referendum campaigns in EU member states. Brussels: European Parliament. Retrieved from https://www. europarl.europa.eu/RegData/etudes/STUD/2015/ 519217/IPOL_STU(2015)519217_EN.pdf

Verger, C. (2018). Transnational lists: A political opportunity for Europe with obstacles to overcome. (Policy Paper No. 216.7). Paris: Jacques Delors Institute.

VoteWatch EU. (2018). Winners and losers of the EP plenary February 2018. VoteWatch EU. Retrieved from https://www.votewatch.eu/blog/winners-andlosers-of-the-ep-plenary-february-2018

\section{About the Author}

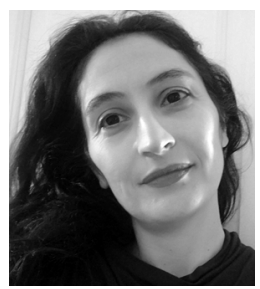

Zoe Lefkofridi is Associate Professor of Comparative Politics at the Department of Political Science and Sociology, and Fellow at the Salzburg Center of European Studies (SCEUS) of the University of Salzburg. Zoe draws on normative and positive theories to analyze democracy, European integration, and inequalities in political representation. Her work appears in European Political Science Review, the Journal of Common Market Studies, West European Politics, and Politics \& Gender, among other journals. 